\title{
Between Don Quixote and Hamlet: vicissitudes of contemporary Cultural Psychiatry
}

\author{
Renato D. Alarcón ${ }^{1,2}$
}

\footnotetext{
Department of Psychiatry and Psychology, Mayo Clinic College of Medicine, Rochester, Minnesota, United States.

2 Honorio Delgado Chair, School of Medicine, Universidad Peruana Cayetano Heredia, Lima, Perú.
}

\section{Correspondence:}

Renato D. Alarcón

Facultad de Medicina, Universidad Peruana Cayetano Heredia Campus Sur. Casa Honorio Delgado, Av. Armendariz 445, Miraflores, Lima, Perú. Phone: (510) 451-2363

Email: alarcon.renato@mayo.edu

\section{Citation:}

Alarcón, R. D. Between Don Quixote and Hamlet: vicissitudes of contemporary Cultural Psychiatry. Salud Mental, $41(1), 39-48$. doi: $10.17711 /$ SM.0185-3325.2018.006

\section{(c) (i) (5)}

\begin{abstract}
Background. Although Cultural Psychiatry (CP) has emerged as a significant discipline and body of knowledge in recent decades, it finds itself in a current intense debate about its identity, its contributions, and its future. Objective. To examine conflictive areas of historical, epistemological, clinical, educational, and research interest in the present and future development of CP. Method. A narrative review of outstanding sources, articles, and textbooks on CP that reflect its current vicissitudes; for each area, adequate quotations of Cervantes' Don Quixote and Shakespeare's Hamlet are used. Results. In addition to updating definitions and content, discussions about whether CP is a psychiatric subspecialty, the scope of its diagnostic, clinical and therapeutic applications, evaluation of criticisms and strengths, interactions with other disciplines, as well as reflective speculations about its future, are outlined. Discussion and conclusion. CP is considered the receptacle of many disciplines, the last bastion of humanistic medicine in a globalized world, although its development will always be marked by scholarly debates about contexts, meanings, identities, and competencies regarding its ontological and epistemological components.
\end{abstract}

Keywords: Cultural Psychiatry, history of psychiatry, international psychiatry, social psychiatry, psychiatric diagnosis, integrated medicine.

\section{RESUMEN}

Antecedentes. La Psiquiatría Cultural (PC) es una disciplina y cuerpo de conocimiento de creciente significación en décadas recientes que, sin embargo, es actualmente materia de un debate intenso acerca de su identidad, sus contribuciones y su futuro. Objetivo. Se examinan áreas de conflicto en aspectos históricos, epistemológicos, clínicos, educacionales y de investigación. Método. Revisión narrativa de fuentes relevantes, artículos y textos que reflejan las actuales vicisitudes de la PC; se utilizan citas referenciales apropiadas de Don Quijote, de Cervantes, y Hamlet, de Shakespeare, en tanto que perspectivas opuestas y/o complementarias. Resultados. Además de actualizaciones de definición y contenidos, se discute si la PC es una subespecialidad psiquiátrica, y se revisan sus aplicaciones diagnósticas, clínicas y terapéuticas; sus críticas y méritos; su interacción con otras disciplinas y reflexiones en torno a su futuro. Discusión y conclusión. La PC es el receptáculo de muchas disciplinas, el último bastión de una medicina humanística en un mundo globalizado, pero su futuro estará marcado siempre por debates académicos acerca del contexto, los significados, las identidades y las competencias respecto a sus componentes ontológicos y epistemológicos.

Palabras clave: Psiquiatría Cultural, historia de la psiquiatría, psiquiatría internacional, psiquiatría social, diagnostico psiquiátrico, medicina integrada. 


\section{BACKGROUND}

Few fields within the whole scope of psychiatry have witnessed in the last few decades the level of development, recognition, and acceptance reached by the cultural inquiry of clinical, educational, and research endeavors (Bhugra \& Bhui, 2007; Wintrob, 2013; Lim, 2015). On the basis of a cogent definition of culture, this line of study enlists the variety of cultural variables (from ethnicity to religion, from traditions to language, or from socio-economic status to sexual orientation) to assess etio-pathogenic, diagnostic, management, or prognostic perspectives about mental conditions (Tseng, 2001; Alarcón, 2013). Cultural concepts assist clinicians and researchers in a more valid approach to integrated knowledge and integrated care, two well recognized pillars of today's medical practice.

These advances are more valuable because they are taking place in a period of medical history dominated by the impressive accomplishments of basic and biological studies, documented in psychiatry by the strong presence of neurosciences and their products. Some authors have acknowledged an almost parallel progress of neurobiological and socio-cultural facture, heated debates, and ontological conflicts notwithstanding. Cultural Psychiatry (CP) can still claim to be a young discipline, in spite of the ancient role of culture and cultural factors and practices in mental health and mental illness. No other than Emil Kraepelin is considered by many as the founder of the discipline after his 1920's travelling to Java and Indonesia to compare and prove the uniformity of clinical manifestations of Dementia Praecox in people culturally very different from his European patients (Favazza \& Oman, 1978; Jilek, 1995). Thus, the modern history of CP may not be older than 100 years, with historical peaks as the contributions of the Columbia and McGill schools, and names as Prince, Wittkower, Morton, and others in Europe and North America. More recent developments and contributions from regions such as Asia, Africa, and Latin America (Wittkower \& Prince, 1974; Tseng, 2001; Alarcón, 2004; Villaseñor-Bayardo, 2016) must also be mentioned.

Nevertheless, and perhaps due to the evidence of its own progress, the current landscape of $\mathrm{CP}$ in the world is both a fascinating and a challenging mix of achievements and obstacles. Very few people nowadays can deny the vigor and the value of cultural ideas, concepts, and variables in the occurrence and the study of psychiatric conditions. Clinical scales, diagnostic tools, and initial sketches of biological correlates are very promising pathways (Bhattacharya, Cross, \& Bhugra, 2010). At the same time, however, pointed out deficiencies, a tendency to "softness" in research efforts (particularly when compared with the "hard science" procedures of neurobiological studies), and deeper debates regarding its essential and auxiliary disciplines and the extent of its epistemological territory are significant components of its position in today's psychiatry and medicine.

Thus, the purpose of this article is to review the present status of $\mathrm{CP}$, opening up both a self-examination and a dialogue about such reality. $\mathrm{CP}$ is in the light of many stars but also in the eye of many storms, not the least of which are its identity, its purposes and its scope. They are called here vicissitudes, with the primary Latin etymology (vicissitudinem) of "change, interchange, alternation", or its modern meaning of "a passing from one state to another", but without the accessory implications of fatalism, anguish, or negativity (Merriam-Webster Dictionary, 2017). The vicissitudes of contemporary CP entail an examination of present and future situations and developments, contents, strengths and criticisms, as well as formulations of perspectives and strategies.

At one point in the preparation of this document, Miguel de Unamuno's (1966) classical notion of agony as fight and contest, as a fate-searching enterprise was considered an appropriate referent. Later, however, and on the basis of the necessarily dual perspective of a topic like this, the journeys of Don Quixote (translated by Grossman, 2009) and Hamlet (edited by Mowat \& Werstine, 2003) were chosen as metaphorical equivalents of the exploratory routes and their analysis. The iconic, complex, and seemingly contradictory characters of two master literary opuses allow the use of statements chosen to reflect different angles in the various areas of the discussion. Don Quixote, vested of firm convictions and certainties, mixed with the idealism and optimism of illusory perceptions and cognitive excesses dealt with stoicism in the face of adversity and in a final, hope-charged lucidity. We read, for instance:

What giants? said Sancho Panza.

Those you see over there, replied his master, with the long arms; sometimes they are almost two leagues long.

Look, your grace, Sancho responded, those things that appear over there aren't giants but windmills, and what looks like their arms are the sails that are turned by the wind and make the grindstone move.

It seems clear to me, replied Don Quixote, that thou art not well-versed in the matter of adventures: these are giants; and if thou are afraid, move aside and start to pray whilst I enter with them in fierce and unequal combat.

(M. de Cervantes, Don Quixote, $1^{\text {st }}$ Part, Chapter VIII)

On his side, Hamlet voiced abundant doubts and even contradictions, expected anguish, pessimistic perceptions not without realistic deliberations or pretentiousness. Here is his classic declaration:

To be, or not to be? That is the question. Whether 'tis nobler in the mind to suffer the slings and arrows of outrageous fortune. Or to take arms against a sea of troubles...

(W. Shakespeare, Hamlet, Act 3, Scene 1) 
The not-so-hidden purpose of this work would then be to outline a balanced vision of a desirable future for $\mathrm{CP}$ across the world.

\section{General perspectives}

The notion of "continuous change" implicit in any approach to the vicissitudes of contemporary $\mathrm{CP}$ has a first incentive in the already mentioned youth of our discipline. As such, a variety of topics reflect the restlessness and the excitement of early developments and their future sequences. Aspects of the definitions of culture, cultural psychiatry, identity, and cultural variables can only be considered provisional at this stage, and leave the door open to heterogeneity, diversity, or variety. One important issue, for instance, is the delineation of disciplinary boundaries aimed at distinguishing cultural psychiatry from similar fields, that is, social psychiatry, clinical, or behavioral anthropology, etc.

The above implies also specific themes, topics, terrains, and levels of study, that is, content issues, and the description, assessment, and management of psychiatric conditions as core reflections of the patterning influence of cultural factors within and beyond a bio-psycho-social context, applicable to patients and providers, family, and society. In fact, the field of culture and psychiatric diagnosis is a powerful example of the vicissitudes of boundary and content faced by CP today (Bhugra \& Bhui, 2007; Alarcón, 2009; Lewis-Fernández, Aggarwal, Hinton, Hinton, \& Kirmayer, 2016).

The implementation of principles leading to concrete realizations requires, again, logistic steps in the clinical, teaching, and research sub-fields. Clinically, it is understood that cultural factors confer more or less defined characteristics to symptoms and syndromes which, otherwise, tend to show universal commonalities. Cultural features impact on levels of severity, psychopathological depth, differential diagnoses, and nosological locations of the patient's morbid experiences. Clinical assessment and training methodologies and actual educational techniques must be nourished by solid cultural-epidemiological, emic and etic ethnographic components, and be duly integrated within a cogent research planning (Kirmayer et al., 2011). Likewise, the vicissitudes of $\mathrm{CP}$ need to be examined within a coherent framework that allows the proper interaction of clinical, social science, and neurobiological approaches. This is, undoubtedly, a work in progress.

\section{Definitional and conceptual problems}

Perform the speech just as I taught you, musically and smoothly. If you exaggerate the words the way some actors do, I might as well have some newscaster read the lines. Don't use too many hand gestures; just do a few, gently, like this. When you get into a whirlwind of passion on stage, remember to keep the emotion moderate and smooth... But don't be too tame, either-let your good sense guide you. Fit the action to the word and the word to the action...

(Hamlet, Act 3, Scene 2)

If, by chance, His Majesty asks who performed the deed, tell him it was The Knight of the Lions; from this day forth, I want the name I have had until now, The Knight of the Sorrowful Face, to be changed, altered, turned, and transformed into this, and in doing so, I follow the ancient usage of knights errant, who changed their names whenever they wished, or whenever it seemed appropriate.

(Don Quixote, $2^{\text {nd }}$ Part, Chapter XVII)

Rather than to reiterate a definition, the question of how to conceptualize $\mathrm{CP}$, how to articulate its most relevant and significant features is a crucial step away from a seemingly simple, yet multifaceted issue. Hamlet provides astute advice, whereas Don Quixote suggests what could be called flexibility or adaptability. It can be said that both are right, but the task of integrating these focal definitional tactics entails additional demands.

What is in a name like Cultural Psychiatry? The vicissitudes of an agile and comprehensive definition include several dimensions. First, the expectation of an ecumenical acceptance of the definition, of an "international psychiatry" outreach that can help break the heterogeneity noted at the beginning. Yes, a culturally-oriented psychiatry must have an international extent but meeting this requirement through a name would not be enough, it would make for an incomplete definition, uncovering the limitations of epidemiology if considered the only substantial component of the concept (Béhague, Goncalves, \& Victora, 2008).

Second, the study of cultural loads in different regions, continents, or countries, while accepted as purpose of the "comparative psychiatry" type of definition, would again reflect a limited outreach and, in many cases, the inconclusive boundaries of any comparison, the "So, what?" of skeptics and inquisitive observers (Kirmayer \& Minas, 2000). Third, a historical background beyond comparisons led to the term "transcultural" that confers a more dynamic flavor, an evolutionary nature to the discipline it attempts to define and describe (the name, Transcultural Psychiatry is carried, by the way, by the most prestigious international journal on the subject). Similarly, "cross-cultural" could sound more sophisticated than "international" or "comparative", but would retain the static appearance of one or the other.

Fourth, is "social psychiatry" the same as cultural psychiatry? The adjective "socio-cultural" used in many contexts seems to suggest that such is not the case. The existence of national and world associations of social and cultural psychiatry also tends to weaken sameness, even though the aims and areas of study may look similar. Some authors suggest that "social" psychiatry has no precise defi- 
nition and is, rather, a topic and a set of techniques to assess mental symptoms (Bebbington, 2010). For others, it refers primarily to epidemiological studies (Shepherd, 1983) or reflects a somewhat broader perspective of topics and events, society as the nest of collectively grouped and experienced phenomena, a communal, all-encompassing seal to behavioral, clinical, and interventional actions, social as something totally different from "individual", "individualized", or "personalized" (Rutz, Fernandez, \& Trivedi, 2011; Sorel, 1998; 2016). Cultural, meanwhile, may point more towards specific variables, a more or less uniform set of features shaping up identities, ethnic origins, thinking styles or religious preferences, and assisting in the description, understanding, improving of both the individual and the social group of which he/she is a member (Tseng, 2001). "Social" does not formally or forcefully include "cultural" due to the former's broad and basically descriptive nature, whereas "cultural" can be "social" in terms of phenomenological weight and clinical impact (Dongier \& Wittkower, 1981; Kirmayer \& Minas, 2000; Lim, 2015).

\section{Is Cultural Psychiatry a subspecialty?}

Claudius, the ambitious, calculating, villainous Hamlet's uncle makes a straightforward statement delineating a plan in generic and absolute terms:

C: ... Now, if we agree Hamlet's crazy, then the next step is to figure out the cause of this effect of craziness, or I suppose I should say the cause of this defect, since this defective effect is caused by something. This is what we must do, and that's exactly what needs to be done...

(Hamlet, Act 2, Scene 2)

Don Quijote, in discussing the nature of a book, talks about its purpose, content and impact, encompasses cultural material and challenges its truthfulness:

Books that are... celebrated by... all kinds of persons of every rank and station: can they possibly be a lie, especially when they bear so close a resemblance to the truth and tell us about the father, the mother, the nation, the family, the age, the birthplace, and the great deeds, point by point and day by day, of the knight, or knights, in question?...

\section{(Don Quixote, $1^{\text {st }}$ Part, Chapter L)}

One of the inherent features of today's knowledge is the tendency to specialization or sub-specialization as a seal of wisdom authenticity and, therefore, legitimate intellectual authority. A medical (or psychiatric) subspecialty must possess a variety of characteristics to justify its existence and broad acceptance: essential ones are a specific, well delineated body of knowledge, a special topic or series of topics in need of deeper and more elaborated examination, and the availability and use of a unique set of instruments (Eisenberg, 1986; Srinivasan, Keenan, \&
Yager, 2006; Kandel, Schwartz, Jessell, Siegelbaum, \& Hudspeth, 2013). Similarly, independent research objectives with concrete results, and concomitant teaching or fellowship programs may confer weight to the structural foci of the field.

Does CP exhibit these characteristics? Many clinicians and academicians may respond affirmatively, and present a variety of arguments in favor of their position: academic programs, special courses, clinical rotations, consultation teams, specific journals, research grants, professional organizations, etc. (Beiser, 2011; Greene et al., 2017). They may not, however, give sufficient importance to the exclusionary nature of a subspecialty, the loss of active contacts with the rest of the disciplinary areas. It can come to be seen as an elitist, exotic field in the hands of rigidly minded cultivators (Alarcón, 1998). Furthermore, broader, differing, and continuously changing scopes instill some instability; the message that culture impregnates every behavioral piece, every mood state, every cognitive elaboration, every syndromic expression can get lost in the process, so that the risks of stereotyping and isolation (Richartz, 2000; Jorm \& Oh, 2009) may affect comprehensiveness and formal recognition. It can be said that the disadvantages of being a subspecialty are much heavier than the eventual benefits. The question remains open to debate.

If CP is not a specialty, what else it is not? It can be emphatically said that it is not an anti-biological psychiatry, a new name for old disciplines, a rehash of archaic ideas, a set of folkloric tales, a political ploy or a piece of rhetoric (Alarcón, 1998; Lolas, 2010). Above all, it is a fighting platform of humanism in today's medicine and psychiatry facing threats and attacks from different fronts.

\section{Teaching and clinical applications of Cultural Psychiatry}

Hamlet is answering a question about what do the words say:

Oh, just lies, sir. The sly writer says here that old men have gray beards, their faces are wrinkled, their eyes full of gunk, and that they have no wisdom and weak thighs. Of course I believe it all, but I don't think it's good manners to write it down, since you yourself, sir, would grow as old as I am, if you could only travel backward like a crab.

(Hamlet, Act 2, Scene 2)

Whereas Don Quixote addresses a truly multicultural compositum:

This host facing us is made up and composed of people from diverse nations: here are those who drink the sweet waters of the famous Xanthus... Persians, those notable archers... Arabians, with movable houses; Scythians, as cruel as they are whiteskinned; Ethiopians, with pierced lips; and an infinite number of other nations, whose faces I recognize and see, although I 
do not recall their names. In this other host come those who drink the crystalline currents of the olive-bearing Betis; those who shine and burnish their faces with the liquid of the forever rich and golden Tajo; those clad in iron, ancient relics of Gothic blood... those who tremble in the cold of the wooded Pyrenees and the white peaks of the high Apennines; in short, all those contained and sheltered in the entirety of Europe.

(Don Quixote, $1^{\text {st }}$ Part, Chapter XVIII)

$\mathrm{CP}$ is variety, is diversity that can be systematically dissected and described in the manner Don Quixote does. But it also faces the risk of inexactitudes bordering on the sophisticated lies of fiction, as Hamlet warns. Its content (and teaching) obviously goes beyond descriptive psychiatry or the psychopathology of distant lands, the study of ethnic minorities or of issues related only to migrants or refugees, and the process of acculturation even if faithfully described or measured (Bäärnhielm, Javo, \& Mösko, 2013).

The scope of CP, particularly when applied to clinical events, covers allof the above plus a few essential additions. It addresses cultural factors in all kinds of psychopathology, more so in those less understood or researched upon. Culture applies to all racial, ethnic or population groups as all carry legacies, traditions, beliefs, viewpoints, and opinion trends. It affects diagnosis, levels of pathologization, severity, and styles of management, hopefully influencing also treatment approaches and clinical outcomes. The research-related vicissitudes of CP, while based on epidemiology, social sciences like anthropology, and disciplines like history or linguistics, include the challenge of developing its own heuristic language while making it available and accessible to other disciplines.

Teaching is a challenge, teaching well, an indispensable precept. Here again, our literary mentors differ, as Hamlet responds to Horatio:

Hr: Is that a tradition?

$\mathrm{H}$ : Yes, it is. But though I was born here and should consider that tradition part of my own heritage, I think it would be better to ignore it than practice it. Other countries criticize us for our loud partying. They call us drunks and insult our noble titles. And our drunkenness does detract from our achievements... and lessens our reputations.

(Hamlet, Act 1, Scene 4)

\section{While Don Quixote explains:}

Look, Sancho... I say proverbs when they are appropriate, and when I say them they fit like the rings on your fingers, but you drag them in by the hair, and pull them along, and do not guide them, and if I remember correctly, I have already told you that proverbs are brief maxims derived from the experience and speculation of wise men in the past, and if the proverb is not to the point, it is not a maxim, it is nonsense.

(Don Quixote, $2^{\text {nd }}$ Part, Chapter LXVIII)
The teaching of $\mathrm{CP}$ is not then a simple matter. It needs coherence and clarity of purposes, delineation, and differentiation of content vis-à-vis a purely clinical focus. While carefully preserving the clinical realities of the patient and his/her family, it must be multi-disciplinary and offer a balanced perspective of sound theoretical bases and agile practical (and pragmatic) objectives. Its methodology must include self-reflective, even comparative approaches by students and teachers to be later contextualized in the unique patient-provider clinical encounter, a scenario in which the individual manifestations of collective cultures may entangle, collide, collapse or unite (Compton et al., 1991; Kirmayer et al., 2011; Lim, 2015).

A particular area in this incursion into the vicissitudes of contemporary $\mathrm{CP}$ is that of its relationship with the vigorous, at times arrogant and always productive field of biological psychiatry. Saving the distances, Hamlet and Don Quixote offer picturesque but profound perspectives about health, its ailments and their management. Here is Hamlet:

... It's just like what happens to certain people who have some birth defect (which they are not responsible for, since nobody chooses how he's born), or some weird habit or compulsion that changes them completely. It happens sometimes that one little defect in these people, as wonderful and talented as they may be, will make them look completely bad to other people. A tiny spot of evil casts doubt on their good qualities and ruins their reputations.

(Hamlet, Act 1, Scene 4)

Cervantes' personage, the Caballero de La Mancha, was a firm believer:

It is a balm..., the recipe for which I have memorized, and with it one need not fear death, nor think that one will die of any wound. When I prepare it and give it to you, all you need to do when you see in some battle that they have cut my body in two (as is wont to happen), is to pick up the part of my body that has fallen to the ground, and very artfully, and with great cunning, before the blood congeals, place it on top of the other half still in the saddle, being careful to fit them together precisely and exactly. Then you will give me only two mouthfuls to drink of the balm I have mentioned, and you will see me sounder than an apple.

(Don Quixote, $1^{\text {st }}$ Part, Chapter X)

First of all, as already said, the relationship between these two approaches must not be, does not have to be antagonistic if both assume and accept the complementariness of their primary efforts. Moreover, the very definition of "cultural" can assist in the understanding that everything biological is a cultural creation (Miresco \& Kirmayer, 2006; Griffith, 2014). The gene-environment equation has been, for many decades, a sort of convivial cliché that then became an avoidant, minimizing (by means of generalizing) maneuver to satisfy stereotyped criticisms from both sides. Neurobiologists and neurogeneticists used to consider environment a broad, 
all-encompassing concept that included culture as a generic component (Wexler, 2006); to this, cultural psychiatrists responded by spelling out the many dimensions of culture and the uneven index of neurobiological proofs for such phenomena, the antecedents of the fashionable and still elusive "biological markers" (Summerfield, 2008).

The topic of ethnicity may serve as another bridge between the cultural and biological branches of psychiatry. By implying deeply rooted physical, physiological, psycho-social, and group-based notions of "belongingness", ethnicity is to identity what genetics and neurobiology are to character or temperament (Alarcón, 2013; Ecks, 2016), that is, a conceptual conglomerate of basic attributes that explain or, at least, assist in the understanding of human behaviors.

Thus, ethno- and socio-biological theoretical and heuristic connections are valid predecessors of the more encompassing bio-cultural relationships which modern psychiatry aspires to consolidate. There are, undoubtedly, areas of inquiry that respond to these requirements: creativity and psychopathology put together the highest expressions of human intellect and an honest search of neurobiological correlates (Zaidel, 2014; Jamison, 1993; 2017); the topics of trauma and resilience conjugate genuinely cultural concepts such as family values, social modulating, fighting spirit and stoicism with neuronal systems, brain regions and biochemical patterns resulting from nature-determined experimental approaches (Russo, Murrough, Han, Charney, $\&$ Nestler, 2012). In the same context, functional and endocrine changes found in children and adolescent whose daily domestic life was presided by abuse and violence (Perna, Alciati, Prestia, Torti, \& Nemeroff, 2013; Nemeroff, 2016) demonstrate the close neuro-physiological and neuro-chemical impact of strong socio-cultural phenomena.

Last but not least, a relatively new sub-discipline of uncontestable neurobiological lineage, pharmacogenomics, has utilized concepts from a cultural area, ethnicity, to develop yet another field, ethnopsychopharmacology (Mrazek, 2010; Silva, 2013; Durham \& Thirumaran, 2017), that proposes predictive measures of symptom-response to medications in terms of doses, timing, effectiveness, side effects, follow-up, and prognosis on the basis of genetic profiles, enzyme-coding processes, and family-oriented projections.

\section{Criticisms towards and strengths of Cultural Psy- chiatry}

The advent and sustained growth of CP have generated, as could be expected, accolades and criticisms. These varying qualifications are also entertained by Hamlet and Don Quixote. Shakespeare's character could be a fierce critic:

He used to praise his mother's nipple before he sucked it. He's like so many successful people in these trashy times - he's patched together enough fancy phrases and trendy opinions to carry him along. But blow a little on this bubbly talk, and it'll burst. There's no substance here.

(Hamlet, Act 5, Scene 2)

When Don Quixote asks Sancho what people's opinions are of him, Sancho responds candidly:

As for your grace's valor, courtesy, deeds, and undertakings... there are different opinions. Some say, "Crazy, but amusing"; others, "Brave, but unfortunate"; and others, "Courteous, but insolent"; and they go on and on so much in this vein that they don't leave an untouched bone in your grace's body or mine.

To which, Don Quixote comments dismissively:

Look Sancho... wherever extraordinary virtue resides, there it is persecuted. Very few, if any, of the famous men of the past escaped the slanders of the wicked. Julius Caesar, that most spirited, prudent, and valiant captain, was called ambitious and not particularly clean in his clothing or habits... Alexander... Hercules... Amadis of Gaul... With so many calumnies directed against good men, let them say what they wish about me, as long as there is no more than what you have told me.

(Don Quixote, $2^{\text {nd }}$ Part, Chapter III)

The comments and reactions of different sectors about today's CP may resemble the combination of praise and condemnation, invective and semi-offended, simulated indifference noticed in the expressions from the protagonists of our two stories. Critics have pointed out that CP precepts remain in the periphery of valid knowledge, are vague and not essential proclamations of differences which, when emphasized, only strengthen heterogeneity, polemics and distracting chats. By ignoring similarities, they say, the objective of epistemological homogeneity is abandoned and, with it, the challenging realities of globalization. It is as if CP sets itself aside either as a passive spectator or as a noisy disruptor (Angell, 2011; Turkle, 2011).

In spite of advances, the same critics point out to a lack of adequate didactic, teaching, and learning tools as decisive weaknesses of the discipline. Translating this into the research field, the result is an absence of "hard" scientific data to justify the presence or value of cultural concepts and components in any kind of clinical events: they may be mostly described as mild, irrelevant co-occurrences or casual accompanying circumstances of well-established symptoms like delusions, hallucinations, manic excesses, anxiety attacks, depersonalization, melancholia, hypochondriasis, or the many forms of violence. Neuroscientific research is still far away from a full understanding of these behaviors, and even farther from grasping the essence of beliefs, morality, ethics or esthetics.

The presence and participation of cultural factors in health and disease may not yet be precise but both are undeniable. The increased recognition of their role in clinical conditions has been sanctioned by the main diagnostic and 
classification systems in world psychiatry (World Health Organization, 1994; American Psychiatric Association, 2013) and, even the new Research Domain Criteria (RDoC) acknowledges the existence of "social" domains in need of systematic inquiry (Insel et al., 2010). Likewise, the multidimensional impact of those factors in today's psychiatry reflects culture's roles as an interpretive/explanatory source of multiple behaviors, apathogenic/pathoplastic agent in clinical happenings, a diagnostic/nosological elaboration, a therapeutic/protective tool, and a critical element of management/service interventions for a variety of clinical cases (Kohn, Wintrob, \& Alarcón, 2017).

The growing research productivity of CP's work, and the recognition of its value, is reflected by multiple scholarly and bibliographic sources, international meetings, grant offers, and patient stories. Cultural research not only aims to prove some hypotheses: it can also help to depathologize behaviors considered abnormal by routine or stereotyped assumptions, trigger or shape psychopathological expressions, assist in precising diagnoses and features of severity, depth or preventability, or optimize possibilities of response to treatments (Kirmayer \& Ban, 2013).

Moreover, research in $\mathrm{CP}$ moves from the connections between cultural facts and appropriate neurobiological systems to the neighboring fields of social sciences: migrations and psychopathology, violence of different kinds, gender, and sexual identity issues, actual pertinence of political and religious principles and values when introduced in the collective elan and used to express satisfaction, frustration, determination, or impotence (Lolas, 2013).

\section{DISCUSSION AND CONCLUSION}

The vicissitudes of contemporary $\mathrm{CP}$ are an itinerary of objectives and uncertainties, as they are a roster of modalities to handle them, a mix of determination and vision besides cautiousness and reasonable strategies. That is how, in turn, its future could be shaped.

The preceding pages have outlined areas closely involved with such itinerary. We are dealing with a young discipline that faces issues of identity, definition of boundaries, sets of strengths and weaknesses, positive or discouraging opinions, and prospects. On the other hand, it has demonstrated a vocation for permanence, has accomplished recognition in clinical, educational, and research areas, and keeps a dignified struggle with public health and legislative bodies in order to reach a well-defined goal: to be part of the much voiced integrated treatment approach (World Health Organization, 2010; Shidhaye, Lund, \& Chisholm, 2015; Benjet \& Scott, 2016), and one of the evaluative and management options to be handled by competently trained multidisciplinary teams (Díaz, 2016). Moreover, CP has enough credentials to make community psychiatry practice stronger, at a time in which this approach faces a promising revival (McCarron et al., 2015; Vanderlip, Raney, \& Druss, 2016).

This review has touched upon topics that show ingredients for optimistic developments as much as for negative ones. In that sense, the latter can make the discipline ponder its journey ahead against the background of doubts and ambiguities that Hamlet reflects on in this passage:

Recently, though I don't know why, I've lost all sense of fun, stopped exercising - the whole world feels sterile and empty. This beautiful canopy we call the sky - this majestic roof decorated with golden sunlight — why, it's nothing more to me than disease-filled air. What a perfect invention a human is, how noble in his capacity to reason, how unlimited in thinking, how admirable in his shape and movement, how angelic in action, how godlike in understanding! There's nothing more beautiful. We surpass all other animals. And yet to me, what are we but dust?...

(Hamlet, Act 2, Scene 2)

The field of CP does not seem to deserve such fate, though. In analyzing the realities it confronts, and delineating the pathway towards a better future, it could be better to follow Don Quixote's embedded mix of self-confidence and prudence:

Take careful note of the landmarks, and I shall try not to leave the vicinity... and I shall even be sure to climb up to the highest peaks to watch for your return. Better yet, so that you will not make a mistake and lose your way, you should cut some of the broom that grows in such abundance here, and place the stalks at intervals along the way until you reach level ground, and they will serve as markers and signs, as did the thread of Perseus in the labyrinth, so that you can find me when you return.

(Don Quixote, $1^{\text {st }}$ Part, Chapter XXV)

Culture is a chalice, a receptacle of many-if not all-kinds of human experiences. CP becomes, therefore, a discipline that not only dresses up all the others but also confers them the privilege of a renewed humanism reaching out to a global community, searching for differences, yes, but also catching similarities and working with both. If $\mathrm{CP}$ were a person, it would be devoted to the task of building bridges towards others, but also duly concerned about core issues such as context, meaning and identity (Bhugra \& Bhui, 2007; Kirmayer, 2012; Alarcón, 2013). If that happens, its diagnostic, clinical, and therapeutic achievements will undoubtedly result in a most solid cultural competence of its practitioners.

\section{The future of Cultural Psychiatry}

Nothing is more complex than figuring out the future of any discipline, and $\mathrm{CP}$ is not an exception. The future of Hamlet, a King-to-be, placed at the center of the Court's 
attention is examined by Horatio, a friend, and Marcellus, an officer:

Hr: His imagination is making him crazy.

M: Let's follow him. It's not right to obey his orders to let him go alone.

Hr: Go ahead and follow him. But what does all this mean, where will it all end?

M: It means that something is rotten in the state of Denmark. Hr: If that's true, we should let God take care of it.

M: No, let's follow him.

(Hamlet, Act 1, Scene 4)

On his side, Don Quixote is always demanding truthfulness and intellectual honesty, when dealing with the future of any creative endeavor:

And I shall be so bold as to swear... that your grace is not well-known in the world, which is always unwilling to reward rare talents and praiseworthy efforts... But despite all this, it seems to be that translating from one language to another, unless it is from Greek and Latin, the queens of all languages, is like looking at Flemish tapestries from the wrong side, for although the figures are visible, they are covered by threads that obscure them, and cannot be seen with the smoothness and color of the right side; translating easy languages does not argue for either talent or eloquence, just as transcribing or copying from one paper to another does not argue for those qualities. And I do not wish to infer from this that the practice of translating is not deserving of praise, because a man might engage in worse things that bring him even less benefit.

(Don Quixote, $2^{\text {nd }}$ Part, Chapter LXII)

The main objectives in the future of $\mathrm{CP}$, perhaps a seeding site of more vicissitudes but also a necessary catalogue of priorities, must include a cogent reaffirmation of the academic, theoretical, clinical, and practical purposes and clear definitions and delineations of scope and content. The interactions with other disciplines (commonalities, similarities, differences, and integrative lines) must be matter of permanent communication, analyses, critiques, and mutual feedback. Progressive and relevant research topics, as well as methodological and operational tools and steps, must result from a continuous updating and renewal. All of this will be based on and reflected by organizational strengths leading to Cultural Psychiatry's increasing visibility.

The journey continues. $\mathrm{CP}$ is an intense field of knowledge and practice, one of the richest disciplines in the study of mental health and its surroundings, but also one the most self-questioning and debate-involved intellectual efforts in medical epistemology. The different perspectives used for its study have followed and will continue following the tortuous, yet suggestive path of vicissitudes that both challenge and inspire the best minds in the field. The meanders of these debates are suggestively drawn upon the text and the tone of pronouncements made by Hamlet and Don Quixote throughout their immortal travelogues
(Turgenev, 1860). That is why, rather than falling into a reiteration of thoughts, we can resort to Bloom (2003a; 2003b), the greatest literary critic and student of Hamlet and Don Quixote to formulate a sort of first conclusion of these reflections:

...We cannot know what Don Quixote and Hamlet believe, since they do not share in our limitations. Don Quixote knows who he is, even as the Hamlet of act V comes to know what can be known.

Cervantes stations his Knight quite close to us, while Hamlet always is remote and requires mediation... Hamlet does not believe the will and its object can be brought together: "Our thoughts are ours, their ends none of our own."... Don Quixote refuses such despair yet nevertheless suffers it.

...We cannot know the object of Don Quixote's quest unless we ourselves are Quixotic (note the capital Q)... Cervantes and Shakespeare match each other in genius... because they gave us personalities more alive than ourselves... Don Quixote says that all comparisons are odious. Perhaps they are but this may be the exception... We need... all the help we can get in regard to ultimates (about Hamlet and Don Quixote). Each is as difficult and yet available as is the other. To confront them fully, where are we to turn except to their mutual power of illumination?

Finally, a second conclusion will also be borrowed from one of the most respected thinkers of cultural, and actually of a truly comprehensive psychiatry in today's world, Eisenberg (1996) who, in a fascinating article titled Seed or soil. How does our garden grow? seems to bring together Hamlet's penetrating observations and pervasive cautiousness with Don Quixote's uncompromising faith and wisdom:

... The human genome dictates for all of us our unique capacity for language acquisition, but what language is acquired and, indeed, whether any language is acquired at all, is entirely dependent on the verbal environment into which we are born. The challenge is to understand more fully the interaction between parental style and infant temperament, both of which vary over a considerable range and reflect inborn as well as acquired characteristics, as that interaction shapes the envelope of development. How, then, does our garden grow? Seed and soil both matter -and so do rain and sun and parasites and pesticides and all the other contingencies that intervene between implantation and reaping.

\section{REFERENCES}

Alarcón, R.D. (1998). What cultural psychiatry isn't. Psychline, 2, 27-28.

Alarcón, R.D. (2004). La revolución didáctica en psiquiatría: retos y posibilidades en América Latina. Salud Mental, 27(1), 1-10.

Alarcón, R.D. (2009). Culture, cultural factors and psychiatric diagnosis. World Psychiatry, 8, 131-139.

Alarcón, R.D. (2013). Cultural Psychiatry: A general perspective. In: R.D. Alarcón (Ed.), Cultural Psychiatry, pp. 1-14. Basel: Karger.

American Psychiatric Association. (2013). Diagnostic and Statistical Manual for Mental Disorders (DSM-5). Washington D.C.: American Psychiatric Association. 
Angell, M. (2011). The illusions of psychiatry. The New York Review of Books, 58, 20-22.

Bäärnhielm, S., Javo, C., \& Mösko, M. O. (2013).Opening up mental health service delivery to cultural diversity: Current situation, development and examples from three Northern European countries. In: R.D. Alarcón (Ed.), Cultural Psychiatry (Vol. 33, p. 40-55). Minnesota: Karger Publishers.

Bebbington, P.E. (2010). Why psychiatry has to be social. In: C. Morgan \& D. Bhugra (Eds.), Principles of Social Psychiatry, (2 ${ }^{\text {nd }}$ Ed., pp. 13-29). Chichester: Wiley-Blackwell.

Béhague, D.P., Goncalves, H., \& Victora C.G. (2008). Anthropology and Epidemiology: Learning epistemological lessons through a collaborative venture. Ciencia e SaúdeColetiva, 13(6), 1715-1717.

Beiser, M. (2011). A career in culture and psychiatry research: reflections on forty-plus years. Transcultural Psychiatry, 48(1-2), 6-23.

Bloom, H. (2003a). Hamlet: Poem unlimited. New York: Riverhead.

Bloom, H. (2003b). The Knight in the mirror. London: The Guardian.

Benjet, C. \& Scott, K. (2016). How to understand and reduce the high prevalence of psychiatric disorders. Salud Mental, 39(6), 285-286. doi: 10.17711/SM.01853325.2016 .032

Bhattacharya, R., Cross, A., \& Bhugra, D. (2010). Clinical Topics in Cultural Psychiatry. London: Royal College of Psychiatrists Publications.

Bhugra D. \& Bhui K. (2007). Textbook of Cultural Psychiatry. Cambridge: Cambridge University Press.

Compton, W. M., Helzer, J. E., Hwu, H.-g., Yeh, E.-k., McEvoy, L., Tipp, J. E., \& Spitznagel, E. L. (1991). New methods in cross-cultural psychiatry: psychiatric illness in Taiwan and the United States. American JournalofPsychiatry, 148(12), 1697-1704.

de Unamuno, M. (1966). La agonía del Cristianismo (4 ${ }^{\text {th }}$ Ed.). Madrid, España: Espasa-Calpe, S.A.

Díaz, J.L. (2016). Conocimiento médico y epistemología clínica. Salud Mental, 39(5), 275-280.

Dongier, M. \& Wittkower, E.D. (1981). Divergent views in Psychiatry. Montreal: Harper \& Row.

Durham, D. \& Thirumaran, R. (2017). Psychiatric Pharmacogenetics: From concepts to cases. New York: Fortis Caliga Academic Press.

Ecks, S. (2016). Commentary: Ethnographic critiques of global mental health. Transcultural Psychiatry, 53(6), 804-808. doi: 10.1177/1363461516678720

Eisenberg, L. (1986). Mindlessness and brainlessness in psychiatry. British Journal of Psychiatry, 148(5), 497-508.

Eisenberg, L. (1996). Seed or soil: How does our garden grow?. American Journal of Psychiatry, 153(1), 3-5.

Favazza A.R. \& Oman, R. (1978). Overview: Foundations of Cultural Psychiatry. American Journal of Psychiatry, 135(3), 293-303

Greene, M.C., Jordans, M.J., Kohrt, B.A., Ventevogel, P., Kirmayer, L. J., Hassan, G., ... Tol, W. A. (2017). Addressing culture and context in humanitarian response: preparing desk reviews to inform mental health and psychosocial support. Conflict and Health, 11(1), 21-24. doi: 10.1186/s13031-017-0123-z

Griffith, J.L. (2014). Neuroscience and humanistic psychiatry: a residency curriculum. Academic Psychiatry, 38(2), 177-184. doi: 10.1007/s40596-014-0063-5

Grossman, E. (Trad.). (2009). Don Quixote. New York: Arion Press.

Insel, T., Cuthbert, B., Garvey, M., Heinssen, R., Pine, D. S., Quinn, K., ... Wang, P. (2010). Research domain criteria (RDoC): toward a new classification framework for research on mental disorders. American Journal of Psychiatry, 167(7), 748-751.

Jamison, K.R. (1993). Touched with fire: Manic-Depressive illness and the artistic temperament. New York: Free Press Paperback.

Jamison, K.R. (2017). Robert Lowell, Setting the river on fire: A study of genius, mania and character. New York: Alfred A. Knopf.

Jilek, W.G. (1995). Emil Kraepelin and comparative sociocultural psychiatry. European Archives of Psychiatry and Clinical Neuroscience, 245(4-5), 231-238.

Jorm, A.F. \& Oh, E. (2009). Desire for social distance from people with mental disorders. Australia and New Zealand Journal of Psychiatry, 43(3), 183-200.doi: $10.1080 / 00048670802653349$

Kandel, E., Schwartz, J., Jessell, T., Siegelbaum, S. A., \& Hudspeth, A. J. (2013). Principles of neural science ( $5^{\mathrm{th}} \mathrm{Ed}$.) New York: McGraw-Hill.
Kirmayer, L.J. (2012). Cultural competence and evidence-based practice in mental health: epistemic communities and the politics of pluralism. Social Science and Medicine, 75(2), 249-256.

Kirmayer, L. \& Minas, H. (2000). The future of cultural psychiatry: An international perspective. Canadian Journal of Psychiatry, 45(6), 438-446.

Kirmayer L.J., Fung, K., Rousseau, C., Lo, H. T., Menzies, P., Guzder, J., ... McKenzie, K. (2011). Guidelines for training in cultural psychiatry. Ottawa: Canadian Psychiatric Association.

Kirmayer, L.J. \& Ban, L. (2013). Cultural Psychiatry: Research strategies and future directions. In: R. D. Alarcón (Ed.), Cultural Psychiatry (pp. 97-114). Basel: Karger.

Kohn, R., Wintrob, R.M., \& Alarcón, R.D. (2017). Transcultural Psychiatry. In: B.J. Sadock, V.A. Sadock, \& P. Ruiz (Eds.), Comprehensive Textbook of Psychiatry (10 $10^{\text {th }}$ Ed., pp. 788-809). Philadelphia: Wolters Kluwer.

Lewis-Fernández, R., Aggarwal, N.K., Hinton, L., Hinton, D., \& Kirmayer, L. (2016). DSM-5 Handbook on the Cultural Formulation Interview. Washington, D.C.: American Psychiatric Publishing.

Lim, R. F. (2015). Clinical Manual of Cultural Psychiatry (2 ${ }^{\text {nd }}$ Ed.). Washington D.C.: American Psychiatric Publishing.

Lolas, F. (2010). Psychiatry: medical specialty or specialized profession?. World Psychiatry, 9, 34-35.

Lolas, F. (2013). Bioethical dimensions of Cultural Psychosomatics: The need for an ethical research approach. In: R. D. Alarcón (Ed.), Cultural Psychiatry (pp. 115-122). Basel: Karger.

McCarron, R.M., Bourgeois, J.A., Chwastiak, L. A., Folsom, D., Hales, R. H., Han, J., ...Yu, A. (2015). Integrated medicine and psychiatry curriculum for psychiatry residency training: a model designed to meet growing mental health workforce needs. Academic Psychiatry, 39, 461-465.

Merriam-Webster Dictionary. (2017). London: Encyclopedia Britannica. Retrieved From: SpanishCentral.com

Miresco, M.J. \& Kirmayer, L.J. (2006). The persistence of mind-brain dualism in psychiatric reasoning about clinical scenarios. American Journal of Psychiatry, 163(5), 913-918.

Mowat, B. \& Werstine, P. (eds.). (2003). Hamlet. Washington DC: Folger Library Shakespeare.

Mrazek, D. (2010). Psychiatric Pharmacogenomics. Oxford: Oxford University Press.

Nemeroff, C.B. (2016). Paradise lost: The neurobiological and clinical consequences of child abuse and neglect. Neuron, 89(5), 829-909.

Perna, G., Alciati, A., Prestia, D., Torti, T., \& Nemeroff, C. B. (2013). Is there a link between child abuse and neglect and anxiety disorders?. Minerva Psichiatrica, 54(2), 137-148.

Richartz, M. (2000). Psychiatrist, quo vadis?. Differences between neurology and psychiatry, between molecular- and social engineering as exemplified by standards and continuing education for psychiatrists in the Netherlands. Nervenarzt, 71(7), 518-524.

Russo, S.J., Murrough, J.W., Han, M.-H., Charney, D. S., \& Nestler, E. J. (2012).Neurobiology of resilience. Nature Neuroscience, 15(11), 1475-1484.doi: 10.1038/ nn. 3234

Rutz, W., Fernandez, M., \& Trivedi, J. (2011). Social perspectives on Psychiatry for the Person. International Journal of Person Centered Medicine, 1(1), 140-142.

Shepherd, M. (1983). The origins and directions of social psychiatry. Integrative Psychiatry, 1(3), 86-88.

Shidhaye, R., Lund, C., \& Chisholm, D. (2015). Closing the treatment gap for mental, neurological and substance use disorders by strengthening existing health care platforms: strategies for delivery and integration of evidence-based interventions. International Journal of Mental Health Systems, 9(1), 40-47.

Silva, H. (2013). Ethnopsychopharmacology and Pharmacogenomics. In: Alarcón, R.D. (Ed.) Cultural Psychiatry (pp. 88-96). Basel:Karger.

Sorel, E. (1998). Social Psychiatry: A mission and a vision for the $21^{\text {st }}$ Century. International Medical Journal, 5(4), 247-249.

Sorel, E. (2016). Translating scientific evidence into global health policy: Making mental health count for individuals' and populationss' health. Indian Journal of Social Psychiatry, 32(3), 185-187.

Srinivasan, M., Keenan C.R., \& Yager, J. (2006). Visualizing the future: technology competence development in clinical medicine, and implications for medical education. Academic Psychiatry, 30(6), 480-490. 
Summerfield, D. (2008). How scientifically valid is the knowledge base of global mental health?. British Medical Journal, 336(7651), 992-994.

Turgenev, I. (1860). Hamlet and Don Quixote. Speech presented at the Society for the Aid of Indigent Writers and Scientists, Moscow, Russia.

Turkle, S. (2011). Alone together: Why do we expect more from technology and less from each other. New York: Basic Books.

Tseng, W.-S. (2001). Handbook of Cultural Psychiatry. San Diego: Academic Press.

Vanderlip, E.R., Raney, L.E., \& Druss, B.G. (2016). A framework for extending psychiatrists' roles in treating general health conditions. American Journal of Psychiatry, 173(7), 658-663.

Villaseñor-Bayardo, S. (2016).Vers une Ethnopsychiatrie mexicaine. La médecine traditionelle dans une communauté nahua du Guerrero (Doctoral dissertation). Paris: Harmattan.

Wexler, B.E. (2006). Brain and Culture: Neurobiology, Ideology and Social Change. Cambridge: MIT Press.
Wintrob, R. (2013). Reflections on current research and future challenges in cultural psychiatry. Transcultural Psychiatry 50(6), 765-768.doi: $10.1177 / 1363461513513415$

Wittkower, E.D. \& Prince, R. (1974). A review of transcultural psychiatry. In: S. Arieti (Ed.), American Handbook of Psychiatry (pp. 535-550). New York: Basic Books.

World Health Organization. (1994). International Statistical Classification of diseases and related health problems, $10^{\text {th }}$ revision (ICD-10); Section V, Mental and Behavioural Disorders. Geneva: World Health Organization.

World Health Organization. (2010). WHO Mental Health Gap Action Programme (mhGAP). Geneva: World Health Organization.

Zaidel, D.W. (2014). Creativity, brain and art: biological and neurological considerations. Frontiers in Human Neuroscience, 8, 389-439. 